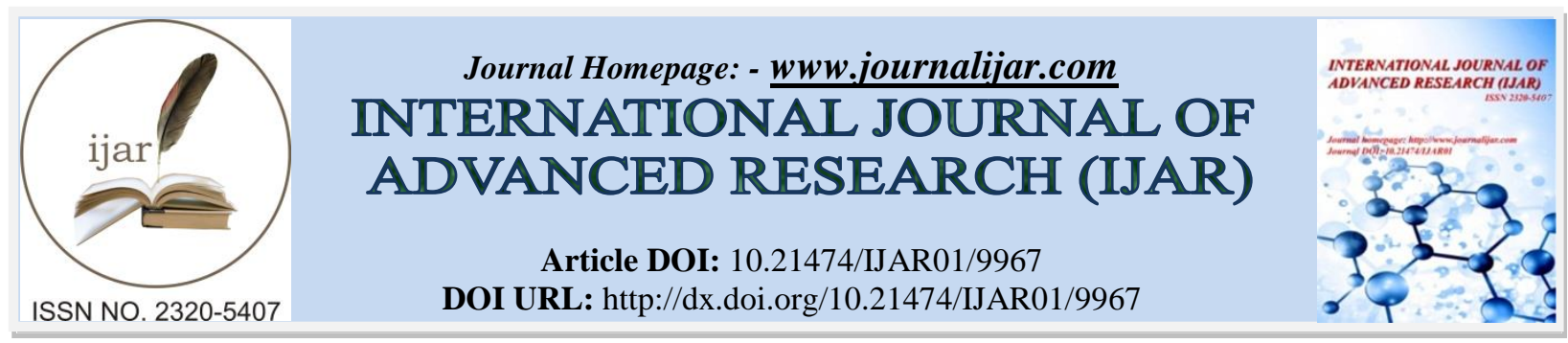

RESEARCH ARTICLE

\title{
BEHAVIOURAL EFFECTS OF ANABAS TESTUDINEUS (BLOCH 1792) TOWARDS SUBLETHAL PARAQUAT EXPOSURE.
}

\section{Nor Azri Shah Norhan ${ }^{1}$, Nurul Ulfah Karim ${ }^{2}$, Hassan Mohd Daud ${ }^{3}$, Anur Abdalah Nagi Melad ${ }^{4}$, Mohd Ihwan} Zakariah $^{1}$ and Marina Hassan ${ }^{1}$.

1. Institute of Tropical Aquaculture and Fisheries, Universiti Malaysia Terengganu, 21030 Kuala Nerus, Terengganu, Malaysia.

2. Faculty of Fisheries and Food Science, Universiti Malaysia Terengganu, 21030 Kuala Nerus, Terengganu, Malaysia.

3. Department of Veterinary Clinical Studies, Universiti Putra Malaysia, 42400 Serdang, Selangor, Malaysia.

4. Department of Biological Science, Faculty of Science, Azzaytuna University, Tarhunah, Libya.

\section{Manuscript Info}

\section{Manuscript History}

Received: 05 September 2019

Final Accepted: 07 October 2019

Published: November 2019

Key words:-

Acute toxicity, Mortality, Behaviour,

Anabas testudineus, Paraquat.

\begin{abstract}
A 96 hours acute toxicity test was completed in order to determine paraquat lethal concentration $50 \%\left(96 \mathrm{H} \mathrm{LC}_{50}\right)$ value towards Anabas testudineus. The fish was subjected to $0,5,10,20,30$ and $40 \mathrm{mgL}^{-1}$ of paraquat under laboratory conditions. Fish mortality rate was directly proportional to paraquat concentration with a total $100 \%$ mortality recorded at $30 \mathrm{mgL}^{-1}$ in 48 hours. The $96 \mathrm{H} \mathrm{LC}_{50}$ value of paraquat was $16.81 \mathrm{mgL}^{-1}$ which is slightly toxic according to United States Fish and Wildlife Service. Regarding behavioural study, a 48 hours sublethal toxicity test was carried out with $2,5,12$, and $15 \mathrm{mgL}^{-1}$ of paraquat. Exposed fish exhibited agitated, respiratory distress and abnormal nervous behaviours which were the earliest response to paraquat The results of present study showed that paraquat is toxic to A. testudineus and any application towards aquatic environment must be handled with caution.
\end{abstract}

Copy Right, IJAR, 2019,. All rights reserved.

\section{Introduction:-}

The uncontrolled use of paraquat by paddy-field farmers raises serious concerns regarding environmental safety. The paraquat is used in weed control and is applied before planting the paddy. The chemical through surface run off reach areas like rivers or streams and become the critical problems to our environment and detrimental to in public health. The chemical properties in water may affect the freshwater aquatic organism, especially fish. The contaminations due to chemicals in waters and land or soil may prove toxic to all classes of living organisms (Kumar et al., 2015).

Anabas testudineus is a freshwater fish of the family Anabantidae which is one of the most common fish found at wet areas of paddy fields in Malaysia. This fish is native to Asia and can live in low water quality or polluted water. A. testudineus is also a strong fish that can survive out of water for about 6 to 10 hours. However, this fish population was reduced because of chemicals for agriculture, especially at the habitat of this fish.

Corresponding Author:- Marina Hassan.

Address:- Institute of Tropical Aquaculture and Fisheries, Universiti Malaysia Terengganu, 21030 Kuala Nerus, Terengganu, Malaysia. 
A sublethal test is a toxicity test that uses a non-lethal concentration of toxicant, either in a short or long-term exposure. The main principle of sublethal test was to study the concentration response relationship between the toxicant and sample without fatality (Broderius et al., 2005). The sublethal exposure caused several physical and physiological effects (Kankaya and Kaptaner, 2014; Suvetha et al., 2010; Patnaik et al., 2011; Gholami-Seyedkolaei et al., 2013). The toxicity of a variety pesticides have been reported for a number of fish species (Naserabad et al., 2015; Patil and David, 2008; Mishra et al., 2011). In aquatic pollution, it is important to test the toxicity levels for their safe levels permissible in the environment. Thus, to assess the safety level of any chemicals for fish, it is important to determine the acute toxic $\mathrm{LC}_{50}$ value.

Behavioural changes are the most affective indications of toxic pollution (Richmonds and Dutta, 1992). The behavioural changes in toxicity test are the important key factors in a basic biological monitoring. Several literatures on this factor were abundantly reported within teleost group against insecticide, herbicide, heavy metal and other stressors (Yilmaz et al., 2004; Mustafa and Murad, 1984; Saglio and Trijasse, 1998; Dutta et al., 1994). The neurotoxicant exposures can alter physiological functions, resulting in abnormal behavioural patterns. An endosulfan can caused severe damage to the brain and convulsions on a target species (Scremin et al., 2011). Organophosphate insecticides inhibit the enzyme, acetylcholinesterase, resulting in increased concentration of the neurotransmitter, acetylcholine and overstimulation of cholinergic pathways (Ferreira et al., 2008). The present study has aimed to determine the lethal concentration $50 \%\left(\mathrm{LC}_{50} 96 \mathrm{H}\right)$ of paraquat and its effects on behaviour to the freshwater fish A. testudineus.

\section{Materials and Methods:- \\ Fish samples}

Adult A. testudineus used in this paraquat challenge test were bought from a local fish farm and had the mean body weight of $40.0 \pm 11.0 \mathrm{~g}$ and mean body length of $13.0 \pm 1.0 \mathrm{~cm}$. The fish was acclimatized for two weeks. Feeding activity was done thrice daily with commercial fish pellets. The healthy fishes were randomly selected and unfed for 24 hours prior to the toxicity test.

\section{Acute Toxicity Test}

Anabas testudineus was subjected to paraquat in a preliminary finding range and acute toxicity test. The farmer grade paraquat (PELADANG, Malaysia) was diluted from initial concentration; $135.59 \mathrm{gL}^{-1}$ into a secondary dilution; $100 \mathrm{mgL}^{-1}$ and later to be diluted into smaller series of paraquat concentrations. A preliminary finding range test (FRT) was completed to determine the toxicant concentration in an acute toxicity test (USEPA 2002). The 24 hours preliminary finding range test was conducted by introducing A. testudineus $(n=25)$ to several series of paraquat concentrations $\left(10,20,30,40,50 \mathrm{mgL}^{-1}\right)$.

In an acute toxicity test $\left(96 \mathrm{H} \mathrm{LC}_{50}\right)$, sixty healthy $\mathrm{A}$. testudineus $(40.0 \pm 11.0 \mathrm{~g}$ and $13.0 \pm 1.0 \mathrm{~cm})$ were exposed to several series of paraquat concentrations $\left(0,5,10,20,30\right.$ and $\left.40 \mathrm{mgL}^{-1}\right)$, with a triplicate by following a method from Ada et al (2012). In conjunction to the test, water changes and feeding were prohibited. Mortality observations were done for every two hours. Dead fish was classified if mouth and opercula movement stopped moving and there was no reaction from mechanical stimuli. They were removed immediately from the water (Anur et al., 2011). The $\mathrm{LC}_{50}$ value was derived from the mortalities (Stephan 1977; USEPA 2002; Abedi et al., 2012).

\section{Behaviour study}

Anabas testudineus used in this study had mean body weight of $40.0 \pm 11.0 \mathrm{~g}$ and body length of $13.0 \pm 1.0 \mathrm{~cm}$ ). In a static bioassay of the $48 \mathrm{H}$ test, fifty adult A. testudineus were challenged with four different paraquat concentrations along with a control (triplicate) and 10 fishes used for each concentration based on the $\mathrm{LC}_{50}$ test result. The concentrations for behaviour study were 2, 5, 12 and $15 \mathrm{mgL}^{-1}$. Each clinical sign exhibited by A. testudineus were classified as agitation, respiratory distress and abnormal nervous behaviour. The data of clinical signs display or behaviour were collected according to Benli and Ozkul (2010) and Hassan et al (2013; 2015).

\section{Results:-}

\section{Acute toxicity test}

Interaction between paraquat acute toxicity to A. testudineus revealed the percentage of mortalities proportionally increased in sync with paraquat concentration and exposure time (Table 1). At 24 hours of exposure, 80\% mortalities occurred with $40 \mathrm{mgL}^{-1}$. At 48 hours of exposure, mortalities were increased $20 \%$ in $20 \mathrm{mgL}^{-1} \mathrm{of}$ 
concentration and $100 \%$ in 30 and $40 \mathrm{mgL}^{-1}$. At 96 hours of acute toxicity test, mortalities was $0 \%$ for control, 5 and $10 \mathrm{mgL}^{-1}$ groups, and $100 \%$ for 20,30 and $40 \mathrm{mgL}^{-1}$ of paraquat. Based on these results, it shows that time and concentration of exposure played an important role to A. testudineus death. The calculated value for $96 \mathrm{H} \mathrm{LC}_{50}$ of paraquat is $16.81 \mathrm{mgL}^{-1}$ (Figure 1).

Table 1:-Percentage of mortality of A. testudineus exposure to paraquat for $96 \mathrm{H}$.

\begin{tabular}{|c|c|c|c|}
\hline \multirow{2}{*}{ Concentrations $\left(\mathrm{mgL}^{-1}\right)$} & \multicolumn{3}{|c|}{ Mortality (\%) } \\
\cline { 2 - 4 } & 24 & 48 & 96 \\
\hline Control & 0 & 0 & 0 \\
\hline 5 & 0 & 0 & 0 \\
\hline 10 & 0 & 0 & 100 \\
\hline 20 & 0 & 20 & 100 \\
\hline 30 & 0 & 100 & 100 \\
\hline 40 & 80 & 100 & \\
\hline
\end{tabular}

Figure 1:-Linear relationship of A. testudineus exposed to paraquat; $96 \mathrm{H}$ with $\mathrm{LC}_{50}$ of $16.81 \mathrm{mgL}^{-1}(\mathrm{Y}=2.9752 \mathrm{X}$

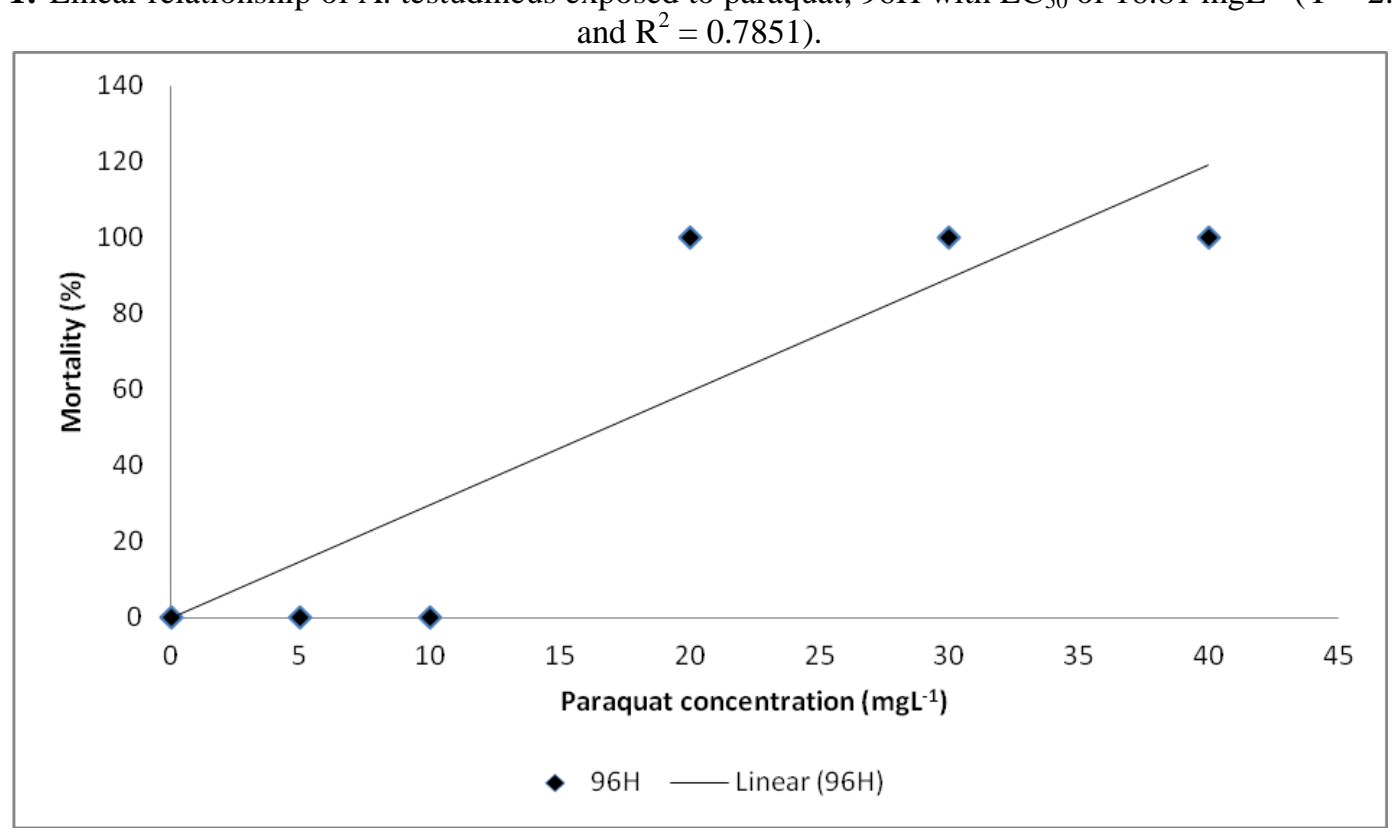

\section{Behaviour study}

Agitated behaviour

Table 2 presents the behavioural response of the A. testudineus to paraquat in different concentrations. The agitated behaviour increased with increased concentration of the paraquat and time exposure. The agitated behaviour that was recorded during 48 hours of experiment was aggression, stunned posture, the fish moved frequently from surface to bottoms and erratic swimming. At higher concentration $15 \mathrm{mgL}^{-1}$, the A. testudineus showed more movement from surface to bottoms, and moderate changes in erratic swimming. The fish was not too aggressive at the highest concentration.

Table 2:-Agitated of A. testudineus subjected to paraquat for $48 \mathrm{H}$.

\begin{tabular}{|c|c|c|c|c|c|}
\hline \multirow{2}{*}{ Clinical Signs } & \multicolumn{5}{|c|}{ Paraquat concentration $\left(\mathrm{mgL}^{-1}\right)$} \\
\cline { 2 - 6 } & 0 & 2 & 5 & 12 & + \\
\hline Aggression & - & + & + & - & + \\
\hline Stunned Posture & - & - & - & +++ & +++ \\
\hline FSBM & - & + & +++ & ++ & ++ \\
\hline
\end{tabular}

Frequent Surface to bottom movements (FSBM).

None (-), Weak (+), Moderate (++), Strong (+++). 


\section{Respiratory distress}

Table 3 presents the respiratory distress behaviour changes at different concentrations. The respiratory distress behaviour increased with increased concentration of paraquat and time of exposure. At concentration $5 \mathrm{mgL}^{-1}$, the respiratory distress started to show strong changes of behaviour including opercula movement, air gulping, vertical posture with exposed snout and excessive mucus secretion.

Table 3:-Respiratory distress of A. testudineus subjected to paraquat for $48 \mathrm{H}$.

\begin{tabular}{|c|c|c|c|c|c|}
\hline \multirow{2}{*}{ Clinical Signs } & \multicolumn{5}{|c|}{ Paraquat concentration $\left(\mathrm{mgL}^{-1}\right)$} \\
\cline { 2 - 6 } & 0 & 2 & 5 & 12 & 15 \\
\hline Opercula Movement & - & + & +++ & +++ & +++ \\
\hline Air Gulping & - & ++ & +++ & +++ & +++ \\
\hline VPES & - & ++ & +++ & +++ & +++ \\
\hline EMS & - & + & +++ & +++ & +++ \\
\hline
\end{tabular}

Vertical Posture with Exposed Snout (VPES), Excessive Mucus Secretion (EMS).

None (-), Weak (+), Moderate (++), Strong (+++).

\section{Abnormal nervous behaviour}

Table 4 presents the behaviour changes related to the nervous system. The fish in condition of motionless in $2 \mathrm{mgL}^{-1}$ and started to slow move with the increased concentration. The other behaviour changes including sluggish and swirling movement started at $5 \mathrm{mgL}^{-1}$ of paraquat concentration. However, the fish showed little changes such as sudden darts from $2 \mathrm{mgL}^{-1}$ until the highest concentration. No fish died in all concentrations tested.

Table 4:-Abnormal nervous behaviour of A. testudineus subjected to paraquat for $48 \mathrm{H}$.

\begin{tabular}{|c|c|c|c|c|c|}
\hline \multirow{2}{*}{ Clinical Signs } & \multicolumn{5}{|c|}{ Paraquat concentration $\left(\mathrm{mgL}^{-1}\right)$} \\
\cline { 2 - 6 } & 0 & 2 & 5 & 12 & 15 \\
\hline SSM & - & - & + & + & + \\
\hline State of Motionless & - & ++ & ++ & ++ & ++ \\
\hline Sudden Darts & - & + & + & + & + \\
\hline DP & - & - & - & + & + \\
\hline Death & - & - & - & - & - \\
\hline
\end{tabular}

Sluggish and Swirling Movements (SSM), Different Posture (DP).

None (-), Weak (+), Moderate (++), Strong (+++).

\section{Discussion:-}

Toxicity test is a survival challenge towards a series of xenobiotic concentrations, either as an acute or chronic exposure (OECD, 2012; HESIS and LOHP, 2008).During the exposure, several effects may occur in test organisms including haematology, histopathology alterations, disruption in ionic regulation and gill activity.

The $\mathrm{LC}_{50}$ value is referred to a specific lethal dosage which causes $50 \%$ mortalities of test subject within a specific test period. In the present study, the $96 \mathrm{HLC}_{50}$ value of paraquat was $16.81 \mathrm{mgL}^{-1}$. Besides, this value can evaluate the toxicant toxicosis during an acute toxicity test, namely in physiological and biological effects. Anabas testudineus mortalities were directly proportional to paraquat concentration and were caused by dosage of xenobiotic and time of exposure (Table 1). These factors were caused a bioaccumulation, where the liver detoxicification activity is lower than toxicant uptake. Thus, it will affect the enzyme inhibition such as acetylcholinesterase inhibition, cellular activity such as energy production, physiological effects such as behavioural changes and death ( Kumar et al., 2016; Hansen et al., 2002; Gholami-Seyedkolaei et al., 2013; Silva et al., 2013). Numerous studies on acute toxicity involving different species of fish with same xenobiotic, resulting in different $\mathrm{LC}_{50}$ value among the fish species itself. Primarily, it is due to different tolerance level of the fish species towards the xenobiotic. The sensitivity is known as a dose-response relationship, that is a fundamental in toxicology (Oulmi et al., 1995). Furthermore, similar relationship was found in the Clarias gariepinus exposed to paraquat (18 $\left.\mathrm{mgL}^{-1}\right)$, Mesopotamichthys sharpeyi $\left(1.11 \mathrm{mgL}^{-1}\right)$, and Oreochromis niloticus $\left(7 \mathrm{mgL}^{-1}\right)$ (Omitoyin et al., 2006; Ada et al., 2012; Safahieh et al., 2012)

Behaviour changes are the most sensitive in indication of potential toxic effects (Farah et al., 2004). Anabas testudineus exhibited a number of behaviour changes when they were exposed to different concentrations of 
paraquat. In this study, the control fish were calm and did not show any stress or aggressive. The behavioural changes can be considered as symptoms of stress on account of the toxicological nature of the environment.

The fish with different concentrations of paraquat showed agitated behaviours such as aggression, stunned posture, frequent surface-to-bottom movements and erratic swimming during the test. The rate of frequent movement from surface to bottom and erratic swimming were increased with the increase of paraquat concentrations. However, the fish showed slight aggression from $2 \mathrm{mgL}^{-1}$ to highest concentration. The fish appeared slightly weak when they are in stunned posture and observed at $15 \mathrm{mgL}^{-1}$. These behaviours were symptoms of loss of coordination and response of fish to paraquat toxicity. The erratic movements and abnormal swimming are triggered by deficiency in nervous and muscular coordination which may be due to accumulation of acetylcholine in synaptic and neuromuscular junction (Rao et al., 2005).

The respiratory distress among A. testudineus was observed at the lowest paraquat concentration, $2 \mathrm{mgL}^{-1}$. The fish increased in surfacing, vertical posture with exposed snout and gulping of surface waters and appeared to avoid breathing in the toxic water. A film of mucus was observed on both body and gill of A. testudineus. It acts as an additional barrier for the A. testudineus in minimizing direct contact with a toxic environment. An excess secretion of mucus all over the body of fish is non-specific response against toxicants and a way to reduce the toxicant contact (Singh et al., 2009).

In toxic environment, the gill was damaged, contributing to a low oxygen consumption which leads to a hypoxia condition. Hypoxic condition triggered the A. testudineus into hyperventilation. In exchange for high oxygen uptake, the hyperventilating A. testudineus had an increment in an opercula movement, VPES and air-gulping behaviours. Similar behaviours were expressed by Labeo rohita (Patil \& David, 2008) for the same purpose as A. testudineus in this experiment. Overall, the respiratory distress expressed by A. testudineus in paraquat exposure was justified as a protection and high oxygen demand under a stressful condition. According to Tilak et al., (2007), the oxygen consumption rate and haemoglobin level was significantly lowered with an increment of xenobiotic concentration. The hemoglobin played an important role in oxygen carrying and energy production during the release of oxygen molecule; aerobic respiration in the tissues. Thus, any affects by paraquat exposure to the gill was responsible for the energy depletion. Dube and Hosetti (2010) also mentioned that the low oxygen consumption and aerobic respiration were affiliated to respiratory distress.

Each group of animals display different collective animal behaviour. The fish exhibit a number of abnormal nervous symptoms when exposed to paraquat for 48 hours such as sluggish and swirling movement, state of motionless, sudden darts, different postures and death. This behaviour occurs because it is triggered by deficiency in nervous and muscular coordination which may be due to accumulation of acetylcholine in synaptic and neuromuscular junctions (Rao et al., 2008; Bell, 2001). Furthermore, the gradual loss of equilibrium and drowning who lead to sluggish and swilling movement, state of motionless and sudden darts behaviours could be the adverse effects of paraquat toxicant on central nervous system. This is due to stressful condition promoted by paraquat exposure. No mortality occurred because the paraquat concentrations used was not the lethal dosage. The results showed that could be low accumulation of toxicant occurring in the fish body. The other possibility is the function of liver detoxified and expelled the toxicant from the body via excretory system. Shiogiri et al., (2012) explained the importance of liver as a detoxification organs and its incompetency caused by the toxicant. High toxicant accumulations will disrupt the fish physiological functions and eventually cause death. But, in the sublethal condition, the toxicant residue was unable to disrupt physiological function and kill the fish (Ikpesu, 2013).

\section{Conclusions:-}

In conclusion, this study reviewed the different changes of fish behaviour with different paraquat concentrations. The concentrations used can be as an indicator for the water polluted by paraquat if the fish die. This information is important for human safety and measurement of the environmental health.

\section{Acknowledgements:-}

We would like to thank the Institute of Tropical Aquaculture and Fisheries (AKUATROP) laboratory and hatchery management for their help. This work was fully supported by the RACES GRANT (56012) from Ministry of Higher Education, Malaysia. 


\section{References:-}

1. Abedi, Z., Khalesi, M., Eskandari, S. K. and Rahmani, H. (2012). Comparison of Lethal Concentrations (LC ${ }_{50^{-}}$ $96 \mathrm{H}$ ) of $\mathrm{CdCl}_{2}, \mathrm{CrCl}_{3}$, and $\mathrm{Pb}\left(\mathrm{NO}_{3}\right)_{2}$ in Common Carp (Cyprinus carpio) and Sutchi Catfish (Pangasius hypophthalmus). Iran. J. Toxicol., 6(18), 672-680.

2. Ada, F. B., Ekpenyong, E. and Ayotunde, E. O. (2012). Haematological, biological and behavioural changes in Oreochromis niloticus (Linne 1757) juveniles exposed to Paraquat herbicide. J. Environ. Chem. Ecotoxicol., 4(3), 64-74. http://doi.org/10.5897/JECE11.067

3. Anur, A. N., Safiah, J., Ikhwanuddin, M. and Marina, H. (2011): Effects of a methanolic extract of Melaleuca cajuputi on African catfish (Clarias gariepinus). In International Fisheries Symposium (pp. 119-121).

4. Bell, A. M. (2001). Effects of an endocrine disrupter on courtship and aggressive behaviour of male threespined stickleback, Gasterosteus aculeatus. Anim. Behav., 62(4), 775-780. http://doi.org/10.1006/anbe.2001.1824

5. Benli, A. Ç. K. and Özkul, A. (2010). Acute toxicity and histopathological effects of sublethal fenitrothion on Nile tilapia, Oreochromis niloticus. Pestic. Biochem. Physiol., 97(1), 32-35. http://doi.org/10.1016/j.pestbp.2009.12.001

6. Broderius, S. J., Kahl, M. D., Elonen, G. E., Hammermeister, D. E. and Hoglund, M. D. (2005). A comparison of the lethal and sublethal toxicity of organic chemical mixtures to the fathead minnow (Pimephales promelas). Environ. Toxicol. Chem., 24(12), 3117-3127.

7. Dube, P. N. and Hosetti, B. B. (2010). Behaviour surveillance and oxygen consumption in the freshwater fish Labeo rohita (Hamilton) exposed to sodium cyanide. Biotechnol. Anim. Husb., 26(1-2), 91-103. http://doi.org/10.2298/BAH1002091D

8. Dutta, H. M., Nassar, S. S., Munshi, J. S. and Richmonds, C. (1994). Behavioral changes in an air-breathing fish, Anabas testudineus, exposed to malathion. Bull. Environ. Contam. Toxicol., 52(1), 80-86. http://doi.org/10.1007/BF00197361

9. Ferreira, A., Maroco, E., Yonamine, M. and Oliveira, M. L. F. de. (2008). Organophosphate and carbamate poisonings in the northwest of Paraná state, Brazil from 1994 to 2005: clinical and epidemiological aspects. Rev. Bras. Ciências Farm., 44(3), 407-415. http://doi.org/10.1590/S1516-93322008000300010

10. Gholami-Seyedkolaei, S. J., Mirvaghefi, A., Farahmand, H. and Kosari, A. A., 2013. Effect of a glyphosatebased herbicide in Cyprinus carpio: Assessment of acetylcholinesterase activity, hematological responses and serum biochemical parameters. Ecotoxicol. Environ. Saf., 98, $135-141$. http://doi.org/10.1016/j.ecoenv.2013.09.011

11. Hansen, J. A., Lipton, J., Welsh, P. G., Morris, J., Cacela, D. and Suedkamp, M. J. (2002). Relationship between exposure duration, tissue residues, growth, and mortality in rainbow trout (Oncorhynchus mykiss) juveniles sub-chronically exposed to copper. Aquat. Toxicol. (Amsterdam, Netherlands), 58(3-4), 175-88. http://doi.org/10.1016/S0166-445X(01)00234-X

12. Hassan, M., Norhan, N. A. S., Chong, J. L., Daud, H. M., Shah, M. M. A. H. and Karim, N. U. (2015). Behavioral and Histopathological Changes of Common Carp (Cyprinus carpio) Exposed to Paraquat. J. Fish. Livest. Prod., 3(2), 2-4. http://doi.org/10.4172/2332-2608.1000131

13. Hassan, M., Zakariah, M. I., Wahab, W., Mohammad, S. D., Idris, N. and Jasmani, S. (2013). Histopathological and Behavioral Changes in Oreochromis sp. after Exposure to Different Salinities. J. Fish. Livest. Prod., 1(2), 2-5. http://doi.org/10.4172/2332-2608

14. HESIS. and LOHP. (2008). Understanding Toxic Substances. In J. Public Health (p. 36). Retrieved from www.cdph.ca.gov/programs/hesis

15. Ikpesu, T. O. (2013). Depuration Technique of Xenobiotics with Reference to Accumulation and Elimination of Paraquat Dichloride in Clarias gariepinus. Iran. J. Toxicol, 7(22), 894-899.

16. Kankaya, E. and Kaptaner, B. (2014). Increased apoptosis in the liver of Chalcalburnus tarici expoed to sublethal concentrations of methyl Parathion. J. Appl. Biol. Sci., 8(1), 45-48.

17. Kumar, N., Ambasankar, K., Krishnani, K. K., Gupta, S. K., Bhushan, S. and Minhas, P. S. (2016). Acute toxicity, biochemical and histopathological responses of endosulfan in Chanos chanos. Ecotoxicol. Environ. Saf., 131, 79-88. http://doi.org/10.1016/j.ecoenv.2016.05.013

18. Kumar, S., Hettiaratchi, P., Ashwath, N. and Gikas, P. (2015). Toxicity of Environmental Contaminants. Biomed Res. Int., 2015. http://doi.org/10.1155/2015/702439

19. Mishra, A., Tripathi, C. P. M., Dwivedi, A. K. and Dubey, V. K. (2011). Acute toxicity and behavioral response of freshwater fish, Mystus vittatus exposed to pulp mill effluent. J. Environ. Chem. Ecotoxicol., 3(6), 167-172.

20. Mustafa, S., \& Murad, A. (1984). Survival, behavioral response and hematological profile of catfish Heteropneustes fossilis exposed to DDT. Japanese J. Ichthyol., 31(1), 55-65. 
21. Naserabad, S. S., Mirvaghefi, A., Gerami, M. H. and Ghafari, H. (2015). Acute Toxicity and Behavioral Changes of the Gold Fish (Carassius auratus) Exposed to Malathion and Hinosan. Iran. J. Toxicol., 8(27), 12031208.

22. OECD. (2012). Fish Toxicity Testing Framework: Series on Testing and Assessment, No. 171. Organisation for Economic Cooperation and Development. Paris, France.

23. Omitoyin, B. O., Ajani, E. K. and Fajimi, O. A. (2006). Toxicity Gramoxone (paraquat) to juvenile African catfish, Clarias gariepinus (Burchell, 1822). Am. J. Agric. Environ. Sci., 1(1), 26-30.

24. Oulmi, Y., Negele, R. D., and Braunbeck, T. (1995). Cytopathology of Liver and Kidney in Rainbow-Trout Oncorhynchus mykiss After Long-Term Exposure to Sublethal Concentrations of Linuron. Dis. Aquat. Organ., 21(1), 35-52. http://doi.org/10.3354/dao021035

25. Patil, V. K., and David, M. (2008). Behaviour and Respiratory Dysfunction as an Index of Malathion Toxicity in the Freshwater Fish, Labeo rohita (Hamilton). Turkish Turkish J. Fish. Aquat. Sci., 8(2), 233-237.

26. Patnaik, B. B., Hongray Howrelia, J., Mathews, T., and Selvanayagam, M. (2011). Histopathology of gill, liver, muscle and brain of Cyprinus carpio communis L. exposed to sublethal concentration of lead and cadmium. African J. Biotechnol., 10(57), 12218-12223. http://doi.org/10.5897/AJB10.1910

27. Rao, J. V. (2008). Brain Acetylcholinesterase Activity as a Potential Biomarker for the Rapid Assessment of Chlorpyrifos Toxicity in a Euryhaline Fish, Oreochromis mossambicus. Environmental Bioindicators, 3(1), $11-$ 22. http://doi.org/10.1080/15555270701779478

28. Rao, J. V., Begum, G., Pallela, R., Usman, P. K. and Rao, R. N. (2005). Changes in behavior and brain acetylcholinesterase activity in mosquito fish, Gambusia affinis in response to the sub-lethal exposure to chlorpyrifos. Int. J. Environ. Res. Public Health, 2(3), 478-483. http://doi.org/10.3390/ijerph2005030013

29. Richmonds, C. and Dutta, H. M. (1992). Effect of malathion on the optomotor behavior of bluegill sunfish, Lepomis macrochirus. Comp. Biochem. Physiol. Part C Comp., 102(3), 523-526. http://doi.org/10.1016/07428413(92)90153-X

30. Safahieh, A., Jaddi, Y., Yavari, V. and Zadeh, R. S.,(2012). Sub-Lethal Effects of Herbicide Paraquat on Hematological Parameters of Benny Fish Mesopotamichthys sharpeyi. In 2nd International Conference on Biotechnology and Environment Management (Vol. 42, pp. 141-145). Singapore: IACSIT Press. http://doi.org/10.7763/IPCBEE.

31. Saglio, P. and Trijasse, S. (1998). Behavioral Responses to Atrazine and Diuron in Goldfish. Arch. Environ. Contam. Toxicol., 35, 484-491.

32. Scremin, O. U., Chialvo, D. R., Lavarello, S., Berra, H. H. and Lucero, M. A. (2011). The environmental pollutant endosulfan disrupts cerebral cortical function at low doses. Neurotoxicology, 32(1), 31-37. http://doi.org/10.1016/j.neuro.2010.12.001

33. Shiogiri, N. S., Paulino, M. G., Carraschi, S. P., Baraldi, F. G., da Cruz, C. and Fernandes, M. N. (2012). Acute exposure of a glyphosate-based herbicide affects the gills and liver of the Neotropical fish, Piaractus mesopotamicus. Environ. Toxicol. Pharmacol., 34(2), 388-396. http://doi.org/10.1016/j.etap.2012.05.007

34. Silva, C., Oliveira, C., Gravato, C. and Almeida, J. R. (2013). Behaviour and biomarkers as tools to assess the acute toxicity of benzo(a)pyrene in the common prawn Palaemon serratus. Mar. Environ. Res., 90, 39-46. http://doi.org/10.1016/j.marenvres.2013.05.010

35. Singh, R. N., Pandey, R. K., Singh, N. N. and Das, V. K. (2009). Acute Toxicity and Behavioral Responses of Common Carp Cyprinus carpio (Linn.) to an Organophosphate (Dimethoate). World Journal of Zoology, 4(2), $70-75$.

36. Stephan, C. E. (1977). Methods for calculating an $\mathrm{LC}_{50}$. In Aquatic toxicology and hazard evaluation (pp. 6584). American Society for Testing and Materials.

37. Suvetha, L., Ramesh, M. and Saravanan, M. (2010). Influence of cypermethrin toxicity on ionic regulation and gill $\mathrm{Na}^{+} / \mathrm{K}^{+}$-ATPase activity of a freshwater teleost fish Cyprinus carpio. Environ. Toxicol. Pharmacol., 29(1), 44-49. http://doi.org/10.1016/j.etap.2009.09.005

38. Tilak, K. S., Veeraiah, K. and Milton, P. R. J. (2007). Effects of ammonia, nitrite and nitrate on hemoglobin content and oxygen consumption of freshwater fish, Cyprinus carpio (Linnaeus). J. Environ. Biol., 28(1), 4547.

39. USEPA, (2002). Methods for Measuring the Acute Toxicity of Effluents and Receiving Waters to Freshwater and Marine Organisms 5th ed. United Stated Environmental Protection Agency.

40. Yilmaz, M., Gül, A. and Karaköse, E. (2004). Investigation of acute toxicity and the effect of cadmium chloride $\left(\mathrm{CdCl}_{2} \cdot \mathrm{H}_{2} \mathrm{O}\right)$ metal salt on behavior of the guppy (Poecilia reticulata). Chemosphere, 56(4), 375-380. http://doi.org/10.1016/j.chemosphere.2003.11.067. 